\title{
Bio Concentration Factor and Translocation Ability of Heavy Metals within Different Habitats of Hydrophytes in Nairobi Dam, Kenya
}

\author{
Ndeda, L. A. ${ }^{1 *}$ and Manohar, S. ${ }^{1}$ \\ ${ }^{I}$ Department of Environmental Sciences, Kenyatta University, Kenya. P.O Box 43844,00100, Nairobi, Kenya.
}

\begin{abstract}
Bio-Concentration Factor (BCF) and Translocation Ability (TA) of Copper (Cu), Cadmium (Cd), Lead $(\mathrm{Pb})$ and Nickel $(\mathrm{Ni})$ in different habitats of hydrophytes within Nairobi dam was carried out during wet and dry seasons. Freshwater plant species from three habitats: (i) free floating; (Eichhornia crassipes), (ii) emergent (attached); (Typha domingensis, Vernonia lasiopus, Cyperus papyrus, Polygonum salicifolium, Rumex bequaertii, Colocasia esculenta, Amaranthus spinosus), and (iii) submerged; (Ceratophyllum demersum); water and sediments were sampled and analysed. Bio Concentration Factor $(B C F)$ of heavy metals was the highest in free floating plants than submerged and lowest in emergent during the wet than dry season. The Translocation Ability (TA) was better in free floating plants in comparison to emergent hydrophytes in the dry season. It is concluded that the free floating specie Eichhornia crassipes has the highest Bio Concentration Factor and Translocation Ability of heavy metals in both dry and wet seasons. Therefore, it is recommended that Eichhornia crassipes should be used for removal of heavy metals from contaminated freshwater bodies and these should not be consumed by animals and humans.
\end{abstract}

Keywords: Bio Concentration Factor, Translocation Ability, Heavy metals, Nairobi dam

\section{Introduction}

Heavy metals are widespread pollutants of great environmental concern as they are non degradable, toxic and persistent with serious ecological ramifications and passes through food chains to humans [1]. These metals disturb growth, development, reduce haemoglobin, create cancer, damage the organs and nervous system, and in extreme cases causes, death [2,3].

The behaviour of heavy metals in natural waters is a function of the substrate, suspended sediment composition, and water chemistry. The water chemistry of the system controls the rate of adsorption and desorption of metals to and from sediment. Adsorption removes the metal from the water column and stores the metal in the substrate. Desorption returns the metal to the water column, where recirculation and bioassimilation may take place. Metals may be desorbed from the sediment if the water experiences increased salinity, decreased redox potential, or decreased $\mathrm{pH}$ [4].

Living organisms require traces of some heavy metals, including cobalt, copper, iron, zinc, manganese and strontium however, excessive levels of essential metals can be harmful to organisms. Non-essential heavy metals of particular concern to surface water systems are Lead, Cadmium, Chromium, Mercury, Arsenic, and Antimony [5].

The Bio-concentration factor refers to the most important plant feature in phytoremediation: the uptake of metals, their mobilization into plant tissues, and storage in the aerial plant biomass [6]. In the aquatic systems, hydrophytes have the potential to uptake heavy metals, and extract large concentrations of heavy metals into their roots and translocate metals to surface biomass [7]. The ecological tolerance of different categories of aquatic plant species vary depending on their specific habits and habitats. Most of the species show different behaviour regarding their ability to accumulate elements in roots, stems and/or leaves, therefore, it is useful to identify the plant and its organ that absorbs the greatest amount of these elements [8]. Phytoremediation has been successfully tested and used in many locations and Superfund sites [9]. A study on removal of heavy metal in wastewater showed that Lemna minor L. and Azolla pinnata R. Br. accumulated 78 times more concentrations of $\mathrm{Cu}$ and $\mathrm{Fe}$ than in the wastewater [10].

Kibera is the largest slum dwellings in Africa on the North eastern bank of Nairobi dam, it is an informal settlement by all standards, and a major contributor to pollution of the Motoine-Ngong river (Fig. 1) mostly due to large quantities of waste emanating from unserviced households, solid and liquid waste, including human waste dumped into trenches that drain into the river, and ends into Nairobi Dam [11]. Therefore, this work intended to analyse bio-concentration factor and translocation ability of heavy metal(s) in the free floating, emergent and submerged hydrophytes of Nairobi dam during wet and dry seasons. 


\section{Study Area}

\section{Materials And Methods}

Nairobi dam is in Langata constituency, Nairobi (Kenya) (Fig. 1) at a latitude of $1^{\circ} 19^{\prime}\left(1.3167^{\circ}\right)$ south; longitude of $36^{\circ} 48^{\prime}\left(36.8^{\circ}\right)$ east. Water accumulation capacity of the dam is $98,422 \mathrm{cu}$. metres $(3,477,800$ $\mathrm{cu} \mathrm{ft}$ ) and surface area of $356,179 \mathrm{~m}^{2}$ (approximately 86 acres). It is situated at an average elevation of 1,686 meters above the sea level.



Figure 1: Map of Kenya showing study area i.e. Nairobi Dam

\section{Data Collection and Analysis}

Dominant peripheral swamp plant species (Typha domingensis, Vernonia lasiopus, Cyperus papyrus, Polygonum salicifolium, Rumex bequaertii, Colocasia esculenta, Amaranthus spinosus); free floating (Eichhornia crassipes); submerged angiosperm, (Ceratophyllum demersum); water and bed sediments were collected once in a month during the wet season (November 2012 to early January 2013) and the dry season (February to early April 2013) from seven selected sites within Nairobi dam: ( $1^{\text {st }}$ sample station was along the stream entering Nairobi dam $10 \mathrm{~m}$ before discharge into the dam; $2^{\text {nd }}$ station: at a distance of $5 \mathrm{~m}$ after discharge into the dam; $3^{\text {rd }}$ station: $5 \mathrm{~m}$ inwards of the west shore; $4^{\text {th }}$ station: $5 \mathrm{~m}$ inwards of the outlet; $5^{\text {th }}$ station: $5 \mathrm{~m}$ inwards of the east shore; $6^{\text {th }}$ station: approximately at the centre of dam; and $7^{\text {th }}$ station: $1 \mathrm{~m}$ from the outlet of the dam). The samples were stored in clean, labelled plastic bags, bottles and jars [12]; then transported to the laboratory where the water was preserved with $1.5 \mathrm{ml} / \mathrm{L}$ Conc. $\mathrm{HNO}_{3}$ and stored in the fridge at $4^{\circ} \mathrm{C}$; sediments were oven dried at $105^{\circ} \mathrm{C}$ for $24 \mathrm{hrs}$ and plants cleaned with clean water and later on, dried in an oven at $80^{\circ} \mathrm{C}$ to constant weight. The dried sediments and plants were ground, after this the sediment(s), plants and water samples were digested separately in $\mathrm{Conc} .3 \mathrm{HNO}_{3}: \mathrm{HCl}[12]$. Heavy metals $(\mathrm{Pb}, \mathrm{Cu}, \mathrm{Cd}, \mathrm{Ni})$ in samples were determined using Shimadzu flame Atomic Absorption Spectrophotometer (AA-630).

Mean metal(s) levels and standard errors were calculated. The Bio concentration factor (BCF) [13] and Translocation Ability (TA) [14] of heavy metal(s) within hydrophytes were calculated as shown below:

$\mathrm{BCF}=$ Plant tissue concentration $\left(\mathrm{mgkg}^{-1}\right)$

Concentration in external environment $\left(\mathrm{mgL}^{-1}\right.$ or $\left.\mathrm{mgkg}^{-1}\right)$

Higher ratio of $\mathrm{BCF}$ implies better phytoaccumulation capabilities.

$\mathrm{TA}=\underline{\text { Root concentration }\left(\mathrm{mgkg}^{-1}\right)}$

Shoot concentration $\left(\mathrm{mgkg}^{-1}\right)$

Higher values of TA imply poorer translocation

\section{Results And Discussion}

The BCF and TA of heavy metals $(\mathrm{Cu}, \mathrm{Cd}, \mathrm{Pb}, \mathrm{Ni})$ in different habitats of hydrophytes within Nairobi dam during wet and dry seasons were analysed. The mean \pm standard errors are tabulated as shown in Table 1 and discussed as follows: 
Table 1: Bio-Concentration factor (BCF) and Translocation Ability (TA) of heavy metals in different habitats of hydrophytes in Nairobi dam during wet and dry seasons

\begin{tabular}{|c|c|c|c|c|c|c|c|}
\hline \multirow{3}{*}{$\begin{array}{l}\text { Heavy } \\
\text { Metals }\end{array}$} & \multirow[t]{3}{*}{$\operatorname{Season}(s)$} & \multicolumn{4}{|c|}{ BCF $($ Mean \pm SE) } & \multicolumn{2}{|c|}{ TA $($ Mean \pm SE)ppm } \\
\hline & & \multirow[t]{2}{*}{ Free floating } & \multicolumn{2}{|c|}{ Emergent (Attached) } & \multirow[t]{2}{*}{ Submerged } & \multirow{2}{*}{$\begin{array}{l}\text { Free } \\
\text { floating }\end{array}$} & \multirow[t]{2}{*}{ Emergent } \\
\hline & & & Sediment & Water & & & \\
\hline \multirow[t]{2}{*}{$\mathrm{Cu}$} & Wet & $5.34 \pm 0.12$ & $0.33 \pm 0.01$ & $2.10 \pm 0.08$ & $4.68 \pm 0.09$ & $1.13 \pm 0.01$ & $1.58 \pm 0.07$ \\
\hline & Dry & $3.68 \pm 0.20$ & $0.38 \pm 0.01$ & $1.69 \pm 0.10$ & $3.29 \pm 0.17$ & $1.20 \pm 0.02$ & $1.55 \pm 0.08$ \\
\hline \multirow[t]{2}{*}{$\mathrm{Cd}$} & Wet & $5.46 \pm 0.23$ & $0.28 \pm 0.01$ & $1.95 \pm 0.09$ & $4.19 \pm 0.17$ & $1.16 \pm 0.01$ & $1.35 \pm 0.05$ \\
\hline & Dry & $4.47 \pm 0.17$ & $0.31 \pm 0.01$ & $1.84 \pm 0.08$ & $3.53 \pm 0.13$ & $1.10 \pm 0.01$ & $1.33 \pm 0.06$ \\
\hline \multirow[t]{2}{*}{$\mathrm{Pb}$} & Wet & $2.55 \pm 0.05$ & $0.53 \pm 0.02$ & $1.54 \pm 0.05$ & $1.77 \pm 0.03$ & $1.08 \pm 0.01$ & $1.36 \pm 0.05$ \\
\hline & Dry & $1.96 \pm 0.03$ & $0.55 \pm 0.01$ & $1.24 \pm 0.03$ & $1.36 \pm 0.02$ & $1.07 \pm 0.01$ & $1.32 \pm 0.06$ \\
\hline \multirow[t]{2}{*}{$\mathrm{Ni}$} & Wet & $1.23 \pm 0.17$ & $0.27 \pm 0.02$ & $1.35 \pm 0.16$ & $0.37 \pm 0.04$ & $2.20 \pm 0.18$ & $1.58 \pm 0.14$ \\
\hline & Dry & $1.37 \pm 0.11$ & $0.37 \pm 0.02$ & $1.47 \pm 0.11$ & $0.39 \pm 0.03$ & $1.65 \pm 0.08$ & $1.41 \pm 0.15$ \\
\hline
\end{tabular}

Sequence of Bio Concentration Factor of heavy metal(s) within the different habitats of hydrophytes during wet and dry seasons was: Free floating > Submerged > Emergent plants in water > Emergent plants in sediments. BCF of Cadmium (Cd) was highest in all the plants and its level in free floating hydrophytes was 4 to 5 times more than those in water (Table 1). This explains the high metals tolerance of Eicchornia crassipes compared to the other categories of hydrophytes.

The hydrophytes had higher BCF values in the wet season than dry season except for the peripheral emergent plants in relation to sediments of Nairobi dam (Table 1). This is due to decreased redox potential in the water column, precipitation that enhanced plant growth, and dilution of heavy metals in the water column in comparison to hydrophytes body during the wet season which resulted to larger ratios (BCF).

"Aquatic macrophytes take up metals from the water, producing an internal concentration several fold greater than their surroundings. Many of the aquatic macrophytes are found to be the potential scavengers of heavy metals from water and wetlands" [15]. Similar results were observed in this study. A study on heavy metals in plants of Sultan Marsh showed that, higher heavy metals concentrations occurred in submerged than in emergent macrophytes [16]. It has also been revealed that submerged plants tend to accumulate higher levels of metals consistently more than emergent or free floating plants $[17,18]$.

The free floating hydrophytes had lower $\mathrm{TA}$ values of $\mathrm{Cu}, \mathrm{Cd}$ and $\mathrm{Pb}$ except of $\mathrm{Ni}$ compared to emergent hydrophytes (Table 1). This shows that the free floating plants had better metals translocation ability than the emergent hydrophytes. This is due to larger surface area to volume ratio of the free floating plants.

Better heavy metals translocation was observed within free floating and attached (emergent) hydrophytes in dry than wet seasons (Table 1). This can be attributed to elevated temperatures in dry season, that enhances evapotranspiration therefore, transporting metals at a faster rate from the soil solution to roots, leaves and stems. Higher temperatures in the dry season also accelerated physical, chemical and biological processes in general thus greater availability of substrate metals as well as higher interior mobility of metals. Lower $\mathrm{pH}$ in water and sediments during dry season increased metals bioavailability in hydrophytes.

A study on ability of Eichhornia crassipes to absorb and translocate $\mathrm{Cd}, \mathrm{Pb}, \mathrm{Cu}, \mathrm{Zn}$, and $\mathrm{Ni}$ in the ErhChung wetlands, revealed that the concentration of these five elements in the roots was 3 to 15 times higher than those in the shoots; and also trace element BCF in water exceeded those in sediment, except for $\mathrm{Cu}$ [19]. Translocation of heavy metals takes time and varies with: hydrophyte species, presence of transporters (carriers and channels), availability of binding sites, energy, environmental conditions ( $\mathrm{pH}$, photosynthesis, temperature etc.), metabolic levels and regulatory proteins among other factors [7,20-24].

\section{Conclusion}

Bio concentration factor (BCF) of heavy metals is highest within the free floating plants than submerged and lowest in emergent (attached) plants of the swamp during wet than dry season. Translocation Ability (TA) of heavy metals in the free floating plants is better than emergent (attached) plants during the dry season. Bio-concentration and translocation of heavy metals are mainly influenced by bioavailability of the heavy metals in both external (sediment and water--associated) and internal (plant and animal--associated) environmental factors. Therefore, it is recommended that free floating Eichhornia crassipes should be adviced 
for removing heavy metals from polluted water bodies and such plants and their products should not be allowed for cultivation, domestic use and commercial purposes.

\section{References}

[1]. Chopra, A. K., Pathak, C. \& Prasad, G. (2009). Scenario of heavy metals contamination in agricultural soil and its management. J. Applied Nat. Sci, 1, 99-108.

[2]. Roberts, JR. (1999). Metal toxicity in children. In: Training Manual on Pediatric Environmental Health. Children's Environmental Health: Emeryville, CA.

[3]. WHO. (2011). Guidelines for Drinking-water Quality. Fourth edition, Malta: Gutenberg. ISBN 9789241548151.

[4]. Connell, B.S., Cox, M. \& Singer, I. (1984). Nickel and Chromium In: Disorders of minerals metabolism, F. Brunner and J. W. Coburn. [Eds.], Academic press: New York. pp. 472-532.

[5]. Kennish, M. J. (1992). Ecology of Estuaries: Anthropogenic Effects, Boca Raton, Florida,USA: CRC Press pp. 494.

[6]. McGrath, S. P., \& Zhao, F. J. (2003). Phytoextraction of metals and metalloids from contaminated soils. Current Opinion in Biotechnology, 14, 277-282.

[7]. Ghosh, M. \& Singh, S. P. (2005). A review on phytoremediation of heavy metals and utilization of its by products. Applied ecology \& environmental research, 3(1),1-18.

[8]. Baldantoni, D., Alfani, A., Di Tommasi, P., Bartoli, G. \& De Santo, A. (2004). Assessment of macro and microelement accumulation capability of two aquatic plants. Environ. Pollut, 130, 149-156.

[9]. Schnoor, J. L. (1997). Phytoremediation. Department of Civil Engineering, University of Lowa. United States. 1, 62.

[10]. Jain, S. K., Vasudevan, P. \& Jha, N. K. (1989). Removal of some heavy metals wastes by aquatic plants: studies on duckweed and water velvet. Biol. Wastes. 28, 115-126.

[11]. UNEP \& IUCN. (2002). Baseline Survey and Environmental Impact Assessment. Nairobi.

[12]. APHA (2005). Standard methods for the Examination of water and waste water. 20 ${ }^{\text {th }}$ Ed. America Public Health Association, Washington DC, USA.

[13]. Zayed, A., Gowthaman, S. \& Terry, N. (1998). Phytoaccumulation of trace elements by wetland plants. Duckweed. J. Environ. Qual. 27, 715-721.

[14]. Wu, F. Y. \& Sun, E. J. (1998). Effects of Copper, Zinc, Nickel, Chromium and Lead on the growth of water convolvulus in water culture. Environ. Prot. 21(1), 63-72.

[15]. Gulati, K. L., Nagpaul, K. K. \& Bukhari, S. S. (1979). Uranium, boron, nitrogen phosphorus and potassium in leaves of mangroves, Mahasagar. Bulletin of the National Institute of Oceanography, 12,183-186.

[16]. Aksoy, A., Demirezen, D. \& Duman, F. (2005). Bioaccumulation, detection and analyses of heavy metal pollution in sultan marsh and its environment. Springer: water, air, and soil pollution, 164, 241-255.

[17]. Outridge, P. M. \& Noller, B. N. (1991). Accumulation of toxic trace elements by freshwater vascular plants. Reviews of Environmental Communication and Toxicology, 121, 1-63.

[18]. Ramdan, A. A. (2003). Heavy metal pollution and biomonitoring plants in Lake Manzala, Egypt. Pak. J. Biol. Sci, 6(13), 11081117.

[19]. Liao, S-W. \& Chang, W-L. (2004). Heavy Metal Phytoremediation by Water Hyacinth at Constructed Wetlands in Taiwan. J. Aquat. Plant Manage. 42, 60-68.

[20]. Dierberg, F. E., DeBusk, T. A. and Goule, N.A. Jr. (1987). In Aquatic Plants for Water Treatment and Resource Recovery. (ed. Reddy K.B. and Smith WH.). Florida: Magnolia Publishing Inc, 497-504.

[21]. Hooda, V. (2007). Phytoremediation of toxic metals from soil and waste water. Journal of Environmental Biology, 28(2), 367-376.

[22]. Nies, D. H. (1999). Microbial heavy metal resistance. Appl. Microbiol. Biotechnol, 51, 730-750.

[23]. Pilon-Smits, E. A. (2005). Phytoremediation. Ann. Rev. Plant Biology, 56, 15-39.

[24]. Williams, L. E., Pittman, J. K. and Hall, J. L. (2000). Emerging mechanisms for heavy metal transport in plants. Biochim. Biophys Acta, 1465(1), 104-126. 